\title{
Effect of Low-dose Chronic Melatonin Administration on Metabolic and Hormonal Variables in Young Laboratory Rats
}

\author{
M. MARKOVÁ, E. ADÁMEKOVÁ, B. BOJKOVÁ, P. KUBATKA, M. KASSAYOVÁ, \\ E. AHLERSOVÁ, I. AHLERS
}

Department of Animal Physiology, Institute of Biological and Ecological Sciences, Faculty of Science, P.J. Safárik University, Košice, Slovak Republic

\author{
Received February 20, 2004
}

Accepted October 26, 2004

\section{Abstract}

Marková M., E. Adámeková, B. Bojková, P. Kubatka, M. Kassayová, E. Ahlersová, I. Ahlers: Effect of Low-dose Chronic Melatonin Administration on Metabolic and Hormonal Variables in Young Laboratory Rats. Acta Vet. Brno 2004, 73: 445-453.

The introduction of melatonin (MEL) as a drug remains open due to insufficient data about the effects of its long-term administration on metabolism. We explored effects of MEL given for 26 weeks at low doses, $4 \mu \mathrm{g} / \mathrm{ml}$ of tap water, on selected metabolic and hormonal indices in young female and male Sprague-Dawley rats.

Male and female rats aged 5 weeks were adapted to standard housing conditions and artificial light regimen $L: D=12: 12 \mathrm{~h}$. The animals were fed standard laboratory diet and drank tap water (controls) or MEL solution ad libitum. Body weight gain, food and water intake was regularly recorded. Oral glucose tolerance tests (OGTTs) were carried out before and 24 weeks after MEL administration. At the end of the experiment following an overnight fast the animals were sacrificed, selected organs and tissues were weighed, selected metabolic indices and hormone concentrations were determined in the serum, liver, heart muscle and bone marrow (femur).

Chronic MEL administration increased in females serum corticosterone concentration, decreased glycogen concentration in the liver and heart muscle, increased triacylglycerol concentration in the bone marrow. An increased absolute weight of periovarial fat and body weight gain were found in last 5 weeks of the experiment. In males, MEL decreased insulin concentration in the serum and body weight gain from week 2 to week 17 of its administration; it decreased relative liver weight in males and females. MEL did not alter food or water intake in both sexes. MEL treatment decreased glucose tolerance (i.e. reduced area under curve values in OGTTs) in males and prolonged the return of afterload glycemia values to initial level in females.

Alterations of carbohydrate metabolism regulation and of body weigth gain were found in both sexes of young rats after long term melatonin administration.

Melatonin, long-term administration, metabolic indices, organ and body weights, males, females

Melatonin (MEL), the main product of the pineal gland, is a low molecular lipophilic hormone, very old from the phylogenetic point of view. Its physiological effects are pleiotropic and it is regarded as "regulator of regulators" (Reiter 1991a). MEL functions as an endogenous synchronizer of biological rhythms and modulates sleep. Therefore exogenous MEL is administered in the treatment of circadian rhythms and other functions imbalances resulting from subsonic or supersonic travel through a varied number of time zones, so called jet-lag syndrome and when working on shifts, so-called shift work-lag syndrome. MEL modulates functions of immune and endocrine system in the organism. Its antioxidizing and oncostatic properties are well-known (Tan et al. $1993 \mathrm{ab}$; Hill and Blask 1988). It displays a wide spectrum of metabolic and other physiological effects including hypothermic, sedative, hypnotic, analgetic, myorelaxing, cardio- and neuroprotective effects (Vijayalax mi et al. 2002; Lagneux et al. 2000; Reiter et al. 1998).

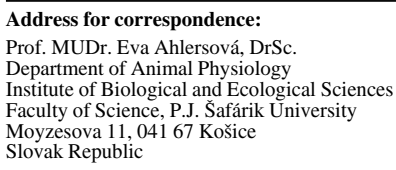


The results of studies investigating MEL effect on carbohydrate and lipid metabolism in experimental animals are controversial, glucose metabolism in particular. In certain studies MEL increased glycemia in rats (Csaba and B arath 1971) and Syrian hamsters (OrtegaCorona et al. 1991) while in the others did not alter it (Bailey et al. 1974) or, on the contrary, decreased it (Iizuka 1996). MEL administration to pinealectomized rats had similar ambiguous effects on glycemia levels (Milcu et al. 1971; C s a ba and B arath 1971; Diaz and Blazquez 1986). In rabbits MEL decreased basal plasma glucose but increased it after glucose load (Dhar et al. 1983). The effect of MEL on glucose level may be explained by modification of insulin secretion and/or change of cell sensitivity to insulin. The results in this area are also controversial as inhibitory (Peschke et al. 1997) or no effects (Frankel and Strandberg, 1991) of MEL on insulin secretion from isolated pancreatic islets in rats and mice were described. Bizot-Espiard et al. (1998) found in an in vivo study that glycemia decrease after insulin load was not affected by MEL administration or pinealectomy, pinealectomy did not significantly alter basal glucose and insulin concentration in the plasma or hepatic glucose and its utilization by tissues when compared with sham-operated rats. MEL is assumed to act directly on target cells e.g. hepatocytes and pancreatic $\beta$-cells (Acuna-Castroviejo et al. 1994; Peschke et al. 2000) and it is possible that MEL and the pineal gland affect glucose metabolism through modulation of activity of suprachiasmatic hypothalamic nucleus (Margraf and Lynch 1993). Effect of exogenous MEL on lipid parameters was more exactly defined. In genetically and diet-induced hypercholesterolemic rats MEL administration decreased serum cholesterol (A yyama et al. 1988; Mori et al. 1989). Esquifino et al. (1997) recorded a decrease in cholesterol in the serum, liver, adrenal glands and testes after pineal extract administration to hyperprolactinemic rats while pinealectomy had the opposite effect. Pharmacological doses of MEL administered in tap water during a period of 3 months reduced increased concentrations of total and LDL-cholesterol and increased plasma HDLcholesterol in young rats fed hypercholesterolemic diet. MEL also decreased malondialdehyde and 4-hydroxyalkenal content in the liver, brain and spleen in rats fed hypercholesterolemic and normal diet (Hoyos et al. 2000). Single subcutaneous MEL administration at a dose of $1 \mathrm{mg} / \mathrm{kg}$ body weight increased concentration of total, free, esterified and HDL cholesterol and decreased the level of free fatty acids in the blood of rats (Fabis et al. 2002). Mechanism of MEL effects on cholesterol metabolism remains unknown. MEL is assumed to affect cholesterol metabolism via influence on cytokine secretion from macrophages - e.g. interleukin 2 (Morrey et al. 1994; Garcia-Mauriño et al. 1997, 1998).

This study is a follow-up research of metabolic effects of MEL ( $4 \mu \mathrm{g} / \mathrm{ml}$ tap water $)$ administered for 10 weeks to Sprague-Dawley rats of both sexes aged 5 weeks (Marková et al. 2003). It is focused on metabolic effects of MEL administered for 26 weeks to young Sprague-Dawley rats including effects on organ weights, adipose intraabdominal tissue and body weight gain.

\section{Materials and methods}

Female and male Sprague-Dawley rats (SD) (Faculty of Medicine, P.J. Šafárik University, Košice, Slovak Republic) aged 36-37 days, weighing 115-140 g were used in the experiment. The animals were adapted to standard housing conditions (temperature $23 \pm 2{ }^{\circ} \mathrm{C}$, relative humidity 60-70\%); artificial light:dark regimen LD 12:12, with lights on at $07.00 \mathrm{~h}$, with intensity 150 lux per cage (TESLA, fluorescent lamps, $40 \mathrm{~W}$ ). The rats were fed standard MP laboratory diet (Top-Dovo, Dobrá voda, Slovak Republic), drank tap water and MEL solution, respectively, ad libitum. Three to five rats were housed per cage.

MEL (Sigma, Diesenhofen, Germany) was administered in tap water at a concentration of $4 \mathrm{mg} / \mathrm{ml}$ discontinuously - from $03.00 \mathrm{~h}$ to $08.00 \mathrm{~h}$ - in the period of increased sensitivity of the organism to MEL (from $08.00 \mathrm{~h}$ to $03.00 \mathrm{~h}$ the animals were drinking tap water) for the period of 26 weeks. Ten $\mathrm{mg}$ of MEL were dissolved in $0.2 \mathrm{ml}$ of $30 \%$ ethanol and mixed up with tap water to the required concentration. The solution of MEL was freshly prepared three times a week. The bottles with MEL solution were covered with a dark foil. The drinking water of control group contained $0.01 \%$ ethanol. 
The animals were divided into 4 groups: females and males that were administered MEL (MEL-treated females, MELtreated males, 9 animals in each group) and control females and males that were not treated with MEL (CONT females, CONT males, 7 animals per group). The rats were weighed twice a week and once a month daily food and water intake was observed (a total of 5 measurements). Oral glucose tolerance tests (OGTTs) were carried out before MEL administration and 24 weeks thereafter as follows: $1 \mathrm{~g}$ of glucose per $1 \mathrm{~kg}$ of body weight in $20 \%$ solution was administered intragastrically to animals following overnight fasting. Twenty-five $\mathrm{ml}$ of the blood was collected from rat tail vein before glucose administration and 15,30,60 and 120 minutes after glucose load. Glucose concentration was determined enzymatically in the blood and presented as graphs. The OGTTs were evaluated by calculation of area under curve (AUC) according to the formula: AUC $(\mathrm{mmol} / \mathrm{h})=\left(\mathrm{G}_{0}+2 \mathrm{G}_{30}+3 \mathrm{G}_{30}+3 \mathrm{G}_{60}+\mathrm{G}_{120}\right) / 4$ where $\mathrm{G}_{0}-\mathrm{G}_{120}$ are the respective blood glucose values. After 26 weeks following overnight fasting the animals were sacrificed by quick decapitation between $08.00 \mathrm{~h}$ and $11.00 \mathrm{~h}$; selected organs (liver, heart muscle, spleen, thymus, adrenal glands) and white fat (periovarial and epididymal) were weighed and the following parameters were determined in the serum, liver, heart muscle and bone marrow (femur):

- in the serum from mixed blood: concentrations of glucose, triacylglycerols, total cholesterol, phospholipids, corticosterone and insulin.

- in the liver: concentrations/contents of glycogen, triacylglycerols, total cholesterol, phospholipids, malondialdehyde (as an indicator of lipoperoxidation).

- in the bone marrow: concentration of triacylglycerols, phospholipids and malondialdehyde.

- in the heart muscle: glycogen concentration/content.

Phospholipids were measured from lipid phosphorus according to Bartlett (1959), total cholesterol according to Zlatkis et al. (1953), glycogen according to Roe and Dailey (1966), malondialdehyde was measured in reaction with thiobarbituric acid (Satch 1978), for triacylglycerol and glucose measurement commercial sets of Lachema (Brno, Czech Republic) were used, insulin by radioimmunoassay with the use of commercial set of Linco Research (St. Charles, MO, USA), corticosterone was measured using fluorimetry according to Guille min et al. (1958).

Results were statistically evaluated by one-way analysis of variance and Kruskall-Wallis test. The criterion for the choice of relevant test was the value of Bartlet's number. Data are presented as means \pm standard error of the mean (S.E.M) and significant differences between groups as: * (a) for $p \leq 0.05 ; * *$ (b) for $p \leq 0.01 ; * * *$ (c) for $\mathrm{p} \leq 0.001$.

The experiment was carried out from May to November.

\section{Results}

During the experiment food and water intake in MEL treated females and males did not differ from the controls. An average daily food and water intake was higher in males in both groups than in females in both groups. Food intake (g): CONT males $27.6 \pm 0.8$ vs CONT females 22.5 $\pm 1.7(p \leq 0.05)$; MEL treated males $26.9 \pm 0.8$ vs MEL treated females $21.4 \pm 1.6(p \leq 0.05)$. Water intake respectively MEL solution (ml): CONT males $39.3 \pm 1.5$ vs CONT females 29.1 $\pm 0.8(\mathrm{p} \leq 0.001)$; MEL treated males $40.8 \pm 1.3$ vs MEL treated females $29.6 \pm 0.3(p \leq 0.001)$. Mean daily MEL intake in females was $118.5 \mu \mathrm{g}$ and in males $163.1 \mu \mathrm{g}$. An average final body weight $(\mathrm{g})$ in male rats of both groups was significantly higher than in females of both groups (CONT males 347.6 \pm 16.0 vs CONT females 159.1 \pm 6.7 ( $p \leq 0.001)$; MEL treated males 348.2

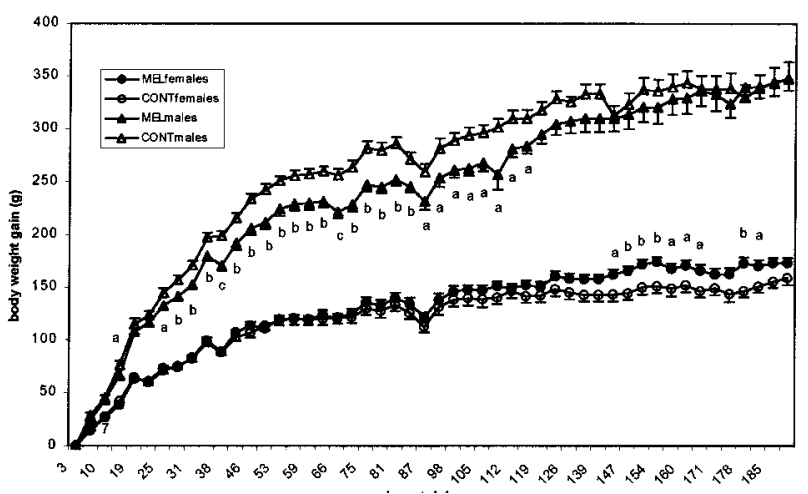

Fig. 1. The effect of 26-week-long MEL administration on body weight of male and female Sprague-Dawley rats

Data in Fig. 1 are expressed as means \pm SEM. Significant differences between groups are designed as: a for $p \leq 0.05$; $\mathrm{b}$ for $p \leq 0.01$; $\mathrm{c}$ for $p \leq$ 0.001 (MEL-group vs CONT-group), CONT-control, MEL-melatonin. \pm 11.9 vs MEL treated females $173.1 \pm 5.1(p \leq 0.001)$. Twenty six weeks MEL administration prominently increased absolute weight of the periovarial fat in females (Table 2) together with their body weight from day 144 to day 182 of the experiment (Fig. 1). Body weight of MEL treated males significantly reduced from day 14 to day 116 ; in the following period the body weight was comparable to that of controls (Fig. 1). The weight of epididymal fat was not significantly influenced by MEL compared to controls (Table 2). Chronic MEL administration 
Table 1

The effect of 26-week-long MEL administration on selected metabolic parameters

\begin{tabular}{|c|c|c|c|c|}
\hline & $\begin{array}{c}\begin{array}{c}\text { CONT-female rats } \\
\mathrm{n}=7\end{array} \\
\end{array}$ & $\begin{array}{c}\text { MEL-female rats } \\
n=9\end{array}$ & $\begin{array}{c}\begin{array}{c}\text { CONT-male rats } \\
\mathrm{n}=7\end{array} \\
\end{array}$ & $\begin{array}{c}\text { MEL-male rats } \\
\mathrm{n}=9\end{array}$ \\
\hline \multicolumn{5}{|l|}{ SERUM } \\
\hline GLU (mmol/l) & $6.17 \pm 0.46$ & $7.14 \pm 0.66$ & $6.47 \pm 0.32$ & $5.63 \pm 0.31$ \\
\hline TAG (mmol/l) & $0.62 \pm 0.05$ & $0.65 \pm 0.05$ & $0.52 \pm 0.03$ & $0.59 \pm 0.06$ \\
\hline $\mathrm{CH}(\mathrm{mmol} / \mathrm{l})$ & $1.44 \pm 0.09$ & $1.38 \pm 0.06$ & $0.96 \pm 0.04$ & $0.93 \pm 0.03$ \\
\hline PL (mmol/l) & $2.12 \pm 0.13$ & $2.03 \pm 0.07$ & $1.13 \pm 0.11$ & $1.08 \pm 0.06$ \\
\hline CTS (pmol/ml) & $350.43 \pm 31.43$ & $761.05 \pm 119.38 *$ & $286.12 \pm 64.37$ & $255.99 \pm 31.32$ \\
\hline INS (ng/ml) & $0.34 \pm 0.03$ & $0.28 \pm 0.05$ & $0.40 \pm 0.08$ & $0.24 \pm 0.03 *$ \\
\hline \multicolumn{5}{|l|}{ LIVER } \\
\hline GLY $( \pm \mathrm{mol} / \mathrm{g})$ & $5.22 \pm 0.36$ & $3.59 \pm 0.48 *$ & $3.50 \pm 0.51$ & $3.47 \pm 0.35$ \\
\hline TAG $( \pm \mathrm{mol} / \mathrm{g})$ & $53.23 \pm 5.83$ & $46.39 \pm 4.02$ & $44.87 \pm 6.63$ & $44.24 \pm 5.06$ \\
\hline $\mathrm{CH}( \pm \mathrm{mol} / \mathrm{g})$ & $21.37 \pm 1.08$ & $19.63 \pm 0.35$ & $19.27 \pm 1.06$ & $20.18 \pm 0.90$ \\
\hline $\mathrm{PL}( \pm \mathrm{mol} / \mathrm{g})$ & $44.52 \pm 1.78$ & $43.98 \pm 1.61$ & $46.70 \pm 0.71$ & $45.47 \pm 0.91$ \\
\hline MDA (nmol/g) & $19.28 \pm 2.68$ & $14.83 \pm 1.98$ & $12.46 \pm 2.16$ & $14.97 \pm 1.76$ \\
\hline \multicolumn{5}{|l|}{ BONE MARROW } \\
\hline TAG $( \pm \mathrm{mol} / \mathrm{g})$ & $55.60 \pm 20.19$ & $120.81 \pm 16.54 *$ & $80.68 \pm 15.05$ & $106.55 \pm 23.89$ \\
\hline $\mathrm{PL}( \pm \mathrm{mol} / \mathrm{g})$ & $16.69 \pm 0.76$ & $16.33 \pm 0.51$ & $14.76 \pm 0.98$ & $15.18 \pm 0.60$ \\
\hline MDA (nmol/g) & $56.45 \pm 4.54$ & $57.16 \pm 8.73$ & $43.62 \pm 16.00$ & $34.62 \pm 3.66$ \\
\hline \multicolumn{5}{|l|}{ HEART MUSCLE } \\
\hline $\mathrm{GLY}( \pm \mathrm{mol} / \mathrm{g})$ & $8.30 \pm 1.26$ & $5.12 \pm 0.61 *$ & $6.92 \pm 0.94$ & $7.61 \pm 0.45$ \\
\hline
\end{tabular}

Data in Table 1 are expressed as means \pm SEM, significant differences between groups are designed as $*$ for $p \leq 0.05$ (MEL-group vs CONT-group). Abbreviations: CONT-controls, MEL-melatonin, GLU-glucose, GLY-glycogen, TAG-triacylglycerols, CH-cholesterol, PL-phospholipids, MDA-malondialdehyde, CTS-corticosterone, INS-insulin, n-number of animals in groups.

significantly increased corticosterone concentration in the serum as well as concentration of triacylglycerols in the bone marrow and decreased glycogen concentration in the liver and heart muscle in females. MEL decreased insulin concentration in the serum in males significantly (Table 1). MEL significantly decreased relative weight of the liver in both females and males; the weights of the other organs were not significantly changed (Table 2). Twenty-four weeks lasting MEL administration modified the curves of OGTTs in males in which significant

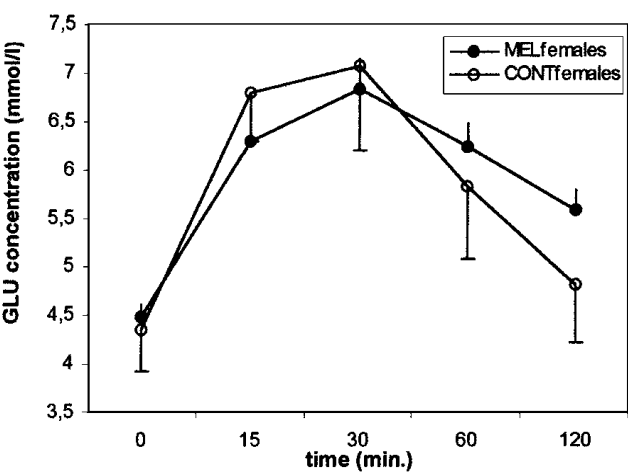

Fig. 2. The course of average OGTTs in control and MEL treated female Sprague-Dawley rats.

Data in Fig. 2 are expressed as means \pm SEM .

Abbreviations: GLU-glucose, CONT-controls $(n=6)$, MEL-melatonin $(n=9)$. reduction of AUC ( $\mathrm{p} \leq 0.01)$ was noticed (Fig. 3, Table 3). In females MEL prolonged the return of glycemia to the initial level in OGTTs but did not change the values of AUC (Fig. 2, Table 3).

\section{Discussion}

In the experiments, preceding this study, MEL was administered to male and female Sprague-Dawley rats aged 5 weeks at the concentration $4 \mu \mathrm{g} / \mathrm{ml}$ in tap water over 2.5 months. In males MEL decreased the concentration of serum triacylglycerols and glycogen liver content, reduced weights of several organs, epididymal fat and body weight gain. Increased liver phospholipid content, weight of the heart muscle and periovarial fat without any changes in body 
Table 2

The effect of 26-week-long MEL administration on weights of selected organs and tissues

\begin{tabular}{|c|c|c|c|c|}
\hline & $\begin{array}{c}\text { CONT-female rats } \\
\qquad \mathrm{n}=7\end{array}$ & $\begin{array}{l}\text { MEL-female rats } \\
\quad \mathrm{n}=9\end{array}$ & $\begin{array}{c}\begin{array}{c}\text { CONT-male rats } \\
\mathrm{n}=7\end{array}\end{array}$ & $\begin{array}{l}\text { MEL-male rats } \\
\quad \mathrm{n}=9\end{array}$ \\
\hline $\begin{array}{l}\text { LIVER } \\
\text { Absolute (g) } \\
\text { relative (\%) }\end{array}$ & $\begin{array}{l}7.14 \pm 0.21 \\
2.88 \pm 0.132\end{array}$ & $\begin{array}{r}6.91 \pm 0.21 \\
.52 \pm 0.07 *\end{array}$ & $\begin{array}{r}12.25 \pm 0.51 \\
2.72 \pm 0.06\end{array}$ & $\begin{aligned} 11.32 & \pm 0.36 \\
2.43 & \pm 0.07 * *\end{aligned}$ \\
\hline $\begin{array}{l}\text { HEART MUSCLE } \\
\text { Absolute }(\mathrm{mg}) \\
\text { relative }(\%)\end{array}$ & $\begin{array}{r}741.00 \pm 19.43 \\
0.30 \pm 0.008\end{array}$ & $\begin{array}{r}769.44 \pm 16.83 \\
0.28 \pm 0.008\end{array}$ & $\begin{array}{r}1195.00 \pm 46.08 \\
0.27 \pm 0.004\end{array}$ & $\begin{aligned} 1204.33 & \pm 36.75 \\
0.26 & \pm 0.009\end{aligned}$ \\
\hline $\begin{array}{l}\text { SPLEEN } \\
\text { Absolute }(\mathrm{mg}) \\
\text { relative }(\%)\end{array}$ & $\begin{aligned} 481.14 & \pm 34.69 \\
0.19 & \pm 0.01\end{aligned}$ & $\begin{array}{r}489.56 \pm 26.57 \\
0.18 \pm 0.009\end{array}$ & $\begin{aligned} 740.57 & \pm 56.07 \\
0.16 & \pm 0.01\end{aligned}$ & $\begin{array}{r}752.67 \pm 45.23 \\
0.16 \pm 0.008\end{array}$ \\
\hline $\begin{array}{l}\text { THYMUS } \\
\text { Absolute (mg) } \\
\text { relative (\%) }\end{array}$ & $\begin{aligned} 183.86 & \pm 18.881 \\
0.07 & \pm 0.008\end{aligned}$ & $\begin{aligned} 61.11 & \pm 12.48 \\
0.06 & \pm 0.005\end{aligned}$ & $\begin{aligned} 149.57 & \pm 12.68 \\
0.034 & \pm 0.004\end{aligned}$ & $\begin{aligned} 145.89 & \pm 12.17 \\
0.031 & \pm 0.004\end{aligned}$ \\
\hline $\begin{array}{l}\text { ADRENALS } \\
\text { Absolute }(\mathrm{mg}) \\
\text { relative }(\%)\end{array}$ & $\begin{aligned} 62.14 & \pm 4.19 \\
0.03 & \pm 0.002\end{aligned}$ & $\begin{aligned} 63.56 & \pm 3.72 \\
0.02 & \pm 0.002\end{aligned}$ & $\begin{aligned} 50.43 & \pm 2.52 \\
0.01 & \pm 0.0005\end{aligned}$ & $\begin{array}{l}55.11 \pm 1.42 \\
0.01 \pm 0.0004\end{array}$ \\
\hline $\begin{array}{l}\text { PERIOVARIAL } \\
\text { FAT } \\
\text { Absolute }(\mathrm{g}) \\
\text { relative }(\%)\end{array}$ & $\begin{array}{l}3.48 \pm 0.76 \\
1.35 \pm 0.26\end{array}$ & $\begin{array}{l}5.82 \pm 0.74 * \\
2.11 \pm 0.25\end{array}$ & - & - \\
\hline $\begin{array}{l}\text { EPIDIDYMAL FAT } \\
\text { Absolute }(\mathrm{g}) \\
\text { relative }(\%)\end{array}$ & - & - & $\begin{array}{l}4.07 \pm 0.62 \\
0.89 \pm 0.13\end{array}$ & $\begin{array}{l}3.21 \pm 0.24 \\
0.69 \pm 0.05\end{array}$ \\
\hline
\end{tabular}

Data in Table 2 are expressed as means \pm SEM, significant differences between groups are designed as: $* *$ for $p \leq 0.01$; * for $p \leq 0.05$ (MEL-group vs CONT-group). Relative weight $(\%)=$ absolute weight $(\mathrm{g} \mathrm{or} \mathrm{mg}$ )/ body weight $\times 100$. MEL-melatonin,CONT-controls, $\mathrm{n}-$ number of animals in groups.

weight gain when compared to controls were recorded in MEL treated females. Normal glucose tolerance after load prevailed in both sexes (Marková et al. 2003). Prolonged period of MEL administration (26 weeks) to rats aged 5 weeks in the present experiment resulted in modifications in carbohydrate metabolism. Prolonged MEL treatment increased serum

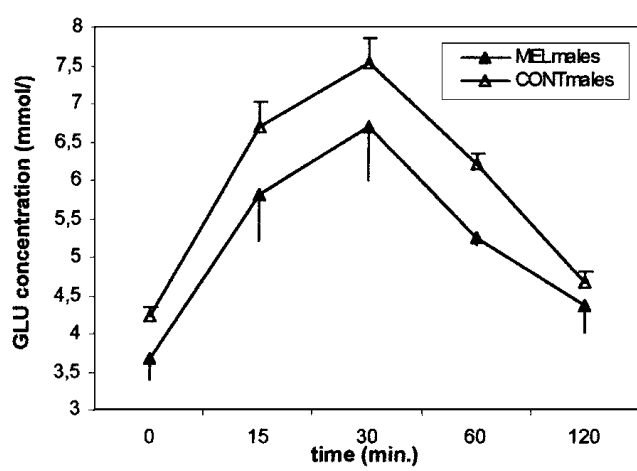

Fig. 3. The course of average OGTTs in control and MEL treated male Sprague-Dawley rats.

Data in Fig. 3 are expressed as means \pm SEM.

Abbreviations: GLU-glucose, CONT-controls $(n=7)$, MEL-melatonin $(n=9)$. corticosterone concentration only in females. In the experiments by Wolden-Han son et al. (2000) three months of MEL administration at low doses $(0.4 \mu \mathrm{g} / \mathrm{ml})$ in tap water to young Sprague-Dawley male rats did not alter plasma corticosterone. However, in 10-month-old (middle-aged) rats MEL restored morning concentration of the aforementioned hormone to the values of young animals. The authors associate the above change with increased glucocorticoid secretion due to MEL effect on the hypothalamic-hypophyseal-adrenal axis and decreased corticosterone clearance, respectively. No bibliographical data were available about the effect of prolonged melatonin administration on serum corticosterone in female rats. Daily MEL 
Table 3

Oral glucose tolerance test results: AUC in male and female SD rats after 24-week long MEL administration

\begin{tabular}{lcccc}
\hline & $\begin{array}{c}\text { CONT- } \\
\text { females } \\
(\mathrm{n}=6)\end{array}$ & $\begin{array}{c}\text { MEL- } \\
\text { females } \\
(\mathrm{n}=9)\end{array}$ & $\begin{array}{c}\text { CONT- } \\
\text { males } \\
(\mathrm{n}=7)\end{array}$ & $\begin{array}{c}\text { MEL- } \\
\text { males } \\
(\mathrm{n}=9)\end{array}$ \\
\hline $\begin{array}{l}\mathrm{AUC} \\
(\mathrm{mmol} / \mathrm{h})\end{array}$ & $15.50 \pm 1.85$ & $15.74 \pm 0.47$ & $16.33 \pm 0.50$ & $\begin{array}{c}14.33 \pm 0.45 \\
* *\end{array}$ \\
\hline
\end{tabular}

Data in Table 3 are expressed as means \pm SEM, significant differences between groupu are designated as

** for $p \leq 0.01$. Abbreviations: AUC - area under the curve, CONT - controls, MEL - melatonin

administration for the period of 6 months did not significantly affect cortisol concentration in older women (Pawlikowski et al. 2000).

Acute decrease in serum insulin in MEL treated males was found; this fact is assumed to be one of the reasons of impaired glucose tolerance after oral load. Decreased serum insulin concentration after prolonged MEL administration to young rats of both sexes was not observed by other authors (Rassmussen et al. 1999, 2001; Mustonen et al. 2002). In middle-aged male Sprague-Dawley rats continuous MEL administration $(4 \mu \mathrm{g} / \mathrm{ml}$ of tap water) decreased age-associated increased plasma insulin and leptin concentration to the values of young animals (Ras s mu s sen et al. 1999, 2001; Wolden-Han s on et al. 2000). Decreased serum insulin concentration may be attributed to inhibition of insulin secretion by MEL as reported by Peschke et al. $(1997,2000)$ in pancreatic islets of healthy rats in the in vitro experiments. MEL released from subcutaneous implants decreased in young diabetic male OLETF (Otsuka Long-Evans Tokushima Fatty) rats increased serum insulin, leptin and triacylglycerol concentration to the values of healthy controls but did not decrease hyperglycemia (Nishida et al. 2002).

Insulin and leptin act centrally as long-term food intake inhibitors and energy expenditure enhancers in mammals (Williams et al. 2001). Twenty-six-week-lasting MEL administration in the present study might have affected serum leptin concentration and together with decreased insulin secretion (concentration) it might decrease the energy expenditure. Increased weight of periovarial fat tissue was recorded as well as increased body weight gain in MEL treated females in the last stage of the experiment. In MEL treated males decreased body weight settled to the level of controls from week 17 to the end of the experiment (week 26).

MEL did not alter average food and water intake in males and females. In MEL-treated males and controls average food and water intake was higher when compared to MEL treated females and control. This fact corresponds with their different mean body weight. Body fat amount is considered the most important factor determining plasma leptin levels; there is a positive correlation between plasma leptin level and body mass index (Maffei et al. 1995). The reason of sexually distinct response of intraabdominal fat tissue to exogenous MEL in males and females in our experiments may have arisen from differences in leptin levels.

Chronic MEL administration to female rats prolonged the return of glycemia to the starting level in OGTTs, the connection with increased serum corticosterone level might be assumed. Decreased liver weight may be associated with decreased liver glycogen content in females. Changes in carbohydrate metabolism in MEL treated males were more outstanding than in females. Higher total intake of MEL in males resulting from higher daily intake of water could cause a decrease of serum insulin concentration (as reported by Peschke et al. 1997, 2000). It resulted in decreased glucose tolerance, manifested as 
significant reduction of AUC-values in OGTTs. Intravenous glucose tolerance tests realized in various times of day did not differ in non-influenced, pinealectomized, melatonin agonistor melatonin antagonist-treated young Wistar rats. In such acute experiments, administration of melatonin agonist did not alter the basal levels of plasma glucose and insulin nor the hepatic glucose production; pinealectomy as chronic melatonin deficiency model did not produce changes of parameters observed, too (Bizot-Espiard et al. 1998). Melatonin agonist or antagonist administration during euglycemic-hyperinsulinemic clamp in young Wistar rats did not change the fall of glycemia after insulin injection (BizotEspiard et al. 1998).

Decreased liver weight in MEL treated males was not accompanied with its decreased glycogen or lipid content. Lipid metabolism parameters in the serum, liver and bone marrow in rats of both sexes were not changed by chronic MEL administration except increased triacylglycerol concentration in the bone marrow in females.

Prolonged 26 weeks lasted MEL administration to young Sprague-Dawley rats of both sexes in our experiments did not have the effect described by Rasmussen et al. (1999, 2001) and Wolden-Han s on et al. (2000) after long-term MEL administration to middleaged rats. We recorded alterations of carbohydrate metabolism parameters, associated with different changes of body weight gain, in males and females.

\section{Vplyv nízkych dávok chronicky podávaného melatonínu na metabolické a hormonálne parametre mladých laboratórnych potkanov}

Otázka dlhodobého používania melatonínu (MEL) ako lieku ostáva stále otvorená pre nedostatočné údaje o jeho pôsobení na metabolizmus. Skúmali sme účinky nízkych dávok MEL ( $4 \mu \mathrm{g} / \mathrm{ml}$ pitnej vody) podávaného 26 týždňov mladým potkanom oboch pohlaví kmeňa Sprague-Dawley na vybrané metabolické a hormonálne parametre.

Potkany vo veku 5 týždňov boli adaptované na štandardné prostredie zvieratníka a umelý svetelný režim $12 \mathrm{~h}$ svetlo - $12 \mathrm{~h}$ tma (L:D = 12:12 h). Zvieratá boli kŕmené štandardnou laboratórnou diétou a napájané pitnou vodou (kontroly) alebo roztokom MEL ad libitum. Pravidelne bol sledovaný prírastok telesnej hmotnosti a príjem potravy a vody. Pred aplikáciou MEL a po 24 týždňoch jeho podávania boli vykonané orálne glukózové tolerančné testy. Na konci pokusu sme zvieratá usmrtili rýchlou dekapitáciou po nočnom hladovaní, vybrané orgány a tkanivá sme zvážili, v sére, pečeni, srdcovom svale a kostnej dreni (femur) sme stanovili koncentrácie metabolických parametrov a hormónov.

U samíc dlhodobé podávanie MEL zvýšilo koncentráciu kortikosterónu $\mathrm{v}$ sére a triacylglycerolov v kostnej dreni, znížilo koncentráciu glykogénu v pečeni a srdcovom svale. MEL zvýšil absolútnu hmotnosṫ periovariálneho tuku a telesnú hmotnosṫ v posledných 5-ich týždňoch pokusu. U samcov MEL znížil koncentráciu inzulínu v sére a telesnú hmotnosṫ od 2. do 17. týždňa podávania. U samcov a samíc MEL znížil relatívnu hmotnost pečene. Podávanie MEL nezmenilo príjem potravy a vody u potkanov oboch pohlaví. Podávanie MEL znížilo u samcov toleranciu glukózy (znížené hodnoty plochy pod glykemickou krivkou) a predížilo návrat hodnôt glykémie po zátaži u samíc.

Po dlhodobom podávaní melatonínu mladým potkanom sme zaznamenali zmeny regulácie glykémie resp. metabolizmu sacharidov a prírastku telesnej hmotnosti u potkanov oboch pohlaví.

\section{Acknowledgements}

The project 1/0442/03 was supported by Grant Science Agency - VEGA, Ministry of Education, Slovak Republic. The experiment was conducted according to the principles provided in the Law No. 115/1995 § 24 of Slovak Republic for the Care and Use of Laboratory Animals.

We thank RNDr. Július Benický, PhD. from the Institute of Experimental Endocrinology, the Slovak Academy of Sciences, Bratislava for his help in insulin determination by RIA as well as Ing. Mária Cermáková, Mrs Renáta Ivanová and Ms Jana Sýkorová of our staff for their technical assistance. 


\section{References}

ACUNA-CASTROVIEJO, D, REITER, RJ, MENENDEZ-PELAEZ, A, PABLOS, MI, BURGOS, A 1994: Characterization of high-affinity melatonin binding sites in purified cell nuclei of rat liver. J Pineal Res 16: 100112

AOYAMA, H, MORI, N, MORI, W 1988: Effects of melatonin on genetic hypercholesterolemia in rats. Atherosclerosis 69: 269

BAILEY, CJ, ATKINS, TW, MATTY, AJ 1974: Melatonin inhibition of insulin secretion in the rat and mouse. Hormone Res 5: 21-28

BARTLETT, GR 1959: Phosphorus assay in column chromatography. J Biol Chem 234: 466-468

BIZOT-ESPIARD, JG, DOUBLÉ, A, COUSIN, B, LESIEUR, D, GUARDIOLA-LEMAITRE, B, DELAGRANGE, P, KTORZA, A, PÉNICAUD, L 1998: Lack of melatonin effects on insulin action in normal rats. Horm Metab Res 30: 711-716

CSABA, G, BARATH, P 1971: Are Langerhans' islets influenced by the pineal body? Experientia 27: 962

DIAZ, B, BLAZQUEZ, E 1986: Effect of pinealectomy on plasma glucose, insulin and glucagon levels in the rat. Horm Metab Res 18: 225-229

DHAR, M, DAYAL, SS, RAMESH BABU, CS, ARORA, SR 1983: Effect of melatonin on glucose tolerance and blood glucose circadian rhythm in rabbits. Ind J Physiol Pharmac 27: 109-117

ESQUIFINO, A, AGRASAL, C, VELÁZQUEZ, E, VILLANUA, MA, CARDINALI, DP 1997: Effect of melatonin on serum cholesterol and phospholipid levels, and on prolactin, thyroid-stimulating hormone and thyroid hormone levels, in hyperprolactinemic rats. Life Sci 61: 1051-1058

FABIŚ, M, PRUSZYNSSKA, E, MAĆKOWIAK, P 2002: In vivo and in situ action of melatonin on insulin secretion and some metabolic implications in the rat. Pancreas 25: 166-169

FRANKEL, BJ, STRANDBERG, MJ 1991: Insulin release from isolated mouse islets in vitro: no effect of physiological levels of melatonin or arginine vasotocin. J Pineal Res 11: 145-148

GARCIA-MAURINO, S, GONZALES-HABA, MG, CALVO, JR, RAFII-EL-INDRISSI, M, SÁNCHESMARGALET, V, GOBERNA, R, GUERRERO, JM 1997: Melatonin enhances IL-2, IL-6 and IFNgamma production by human circulating CD4+ cells: a possible nuclear receptor-mediated mechanism involving Th1 lymphocytes and monocytes. J Immunol 159: 574-581

GARCIA-MAURINO, S, GONZALES-HABA, MG, CALVO, JR, GOBERNA, R, GUERRERO, JM 1998: Involvement of nuclear binding sites for melatonin in the regulation of IL-2 and IL-6 production by human blood mononuclear cells. J Neuroimmunol 92: 76-84

GUILLEMIN, R, CLAYTON, GW, SMITH, JD, LIPSCOMB, HS 1958: Measurement of free corticosteroids in rat plasma. Physiological validation of the method. Endocrinology 63: 349-355

HILL, SM, BLASK, DE 1988: Effects of the pineal hormone melatonin on the proliferation and morphological characteristics of human breast cancer cells (MCF-7) in culture. Cancer Res 48: 6121-6126

HOYOS, M, GUERRERO, JM, PEREZ-CANO, R, OLIVAN, J, FABIANI, F, GARCIA-PERGANEDA, A, OSUNA, CARMEN 2000: Serum cholesterol and lipid peroxidation are decreased by melatonin in diet-induced hypercholesterolemic rats. J Pineal Res 28: 150-155

IIZUKA, Y 1996: Effect of melatonin on serum glucose and insulin levels in rats. Medicine and Biology 133: 65-67

LAGNEUX, C, JOYEUX, M, DEMENGE, P et al. 2000: Protective effects of melatonin against ischemiareperfusion injury in the isolated rat heart. Life Sci 66: 503-509

MAFFEI, M, HALAAS, J, RAVUSSIN, E, PRATLEY, RE, LEE, GH, ZHANG, Y, FEI, H, KIM, S, LALLONE, R, RANGANATHAN, S, KERN, PA, FRIEDMAN, JM 1995: Leptin levels in human and rodent: measurement of plasma leptin and ob RNA in obese and weight-reduced subjects. Nature Med 1: 1155-1161

MARGRAF, RR, LYNCH, GR 1993: Melatonin injections affect circadian behavior and SCN neurophysiology in Djungarian hamsters. Am J Physiol 264: 615-621

MARKOVA, M, ADAMEKOVA, E, KUBATKA, P, BOJKOVA, B, AHLERSOVA, E, AHLERS, I 2003: Effect of prolonged melatonin administration on metabolic parameters and organ weights in young male and female Sprague-Dawley rats. Acta Vet Brno 72: 163-173

MILCU, SM, NANU-IONESCU, I, MILCU, I 1971: The effect of pinealectomy on the plasma insulin in rats. In: WOLTENSHOLME, GEW, KNIGHT, J (Eds): The Pineal Gland. Churchill Livingstone, Edinburgh, pp. 345-377

MORI, N, AOYAMA, H, MURASE, T, MORI, W 1989: Anti-hypercholesterolemic effect of melatonin in rats. Acta Pathol Jpn 39: 613-618

MORREY, KM, McLACHAN, JA, SERKIN, CD, BAKOUCHE, O 1994: Activation of human monocytes by the pineal hormone melatonin. J Immunol 153: 2671-2680

MUSTONEN, AM, NIEMINEN, P, HYVÄRINEN, H 2002: Effect of continuous light and melatonin treatment on energy metabolism of the rat. J Endocrinol Invest 25: 716-723

NISHIDA, S, SEGAWA, T, MURAI, I, NAKAGAWA, S 2002: Long-term melatonin administration reduces hyperinsulinemia and improves the altered fatty-acid compositions in type 2 diabetic rats via the restoration of $\triangle-5$ desaturase activity. J Pineal Res 32: 26-33

ORTEGA-CORONA, BG, ESPARZA-AVALOS, N, BENITEZ-KING, G, PRATZ-GUITRADO, S, ANTÓNTAY, P 1991: Effect of melatonin administration on plasma glucose levels. Proc West Pharmacol Soc 34: 75-77 
PAWLIKOVSKI, M, KOLOMECKA, M, WOJTCZAK, A, KARASEK, M 2002: Effects of six months melatonin treatment on sleep quality and serum concentrations of estradiol, cortisol, dehydroepiandrosterone sulfate, and somatomedin C in elderly women. Neuroendocrin Lett 23: 17-19

PESCHKE, E, PESCHKE, D, HAMMER, T, CSERNUS, V 1997: Influence of melatonin and serotonin on glucosestimulated insulin release from perifused rat pancreatic islets in vitro. J Pineal Res 23: 156-163

PESCHKE, E, FAUTECK, JD, MUSSHOFF, U, SCHMIDT, F, BECKMANN, A, PESCHKE, D 2000: Evidence for a melatonin receptor within pancreatic islets of neonate rats: functional, autoradiographic, and molecular investigations. J Pineal Res 28: 156-164

RASMUSSEN, DD, BOLDT, BM, WILKINSON, CW, YELLON, SM, MATSUMOTO, AN 1999: Daily melatonin administration at middle age suppresses male rat visceral fat, plasma leptin, and plasma insulin to youthful levels. Endocrinology 2: 1009-1012

RASMUSSEN, DD, MITTON, DR, LARSEN, SA, YELLON, SM 2001: Aging-dependent changes in the effect of daily melatonin supplementation on rat metabolic and behavioral responses. J Pineal Res 31: 89-94

REITER, JR, JOAQUIN, J, PIE, G, PIE, J 1998: Oxidative toxicity in models of neurodegeneration: responses to melatonin. Rest Neurol Neurosci 12: 135-142

ROE, JH, DAILEY, R 1966: The determination of glycogen with anthrone reagent. Analyt Biochem 15: 245-250

SATCH, K 1978: Serum lipid peroxide in cerebrovascular disorders determined by a new colorimetric method. Clin Chim Acta 90: $37-43$

TAN, DX, CHEN, LD, POEGELLER, B, MANCHESTER, LC, REITER, RJ 1993a: Melatonin: a potent, endogenous hydroxyl radical scavenger. Endocrin J 1: 57-60

TAN, DX, POEGELLER, B, REITER, RJ, CHEN, LD, CHEN, S, MANCHESTER, LC, BARLOW-WALDEN, LR 1993b: The pineal hormone melatonin inhibits DNA-adduct formation induced by the chemical carcinogen safrole in vivo. Cancer Lett 70: 65-71

VIJAYALAXMI, THOMAS, CR, REITER, RJ, HERMAN, TS 2002: Melatonin: from basic research to cancer treatment clinics. J Clin Oncol 20: 2575-2601

WILLIAMS, G, BING, CH, CAI, XJ, HARROLD, JA, KING, PJ, LIU, XH 2001: The hypothalamus and the control of energy homeostasis. Different circuits, different purposes. Physiol Behav 74: 683-701

WOLDEN-HANSON, T, MITTON, DR, McCANTS, RL, YELLON, SM, WILKINSON, CW, MATSUMOTO, AM, RASMUSSEN, DD 2000: Daily melatonin administration to middle-aged male rats suppresses body weight, intraabdominal adiposity, and plasma leptin and insulin independent of food intake and total body fat. Endocrinology 2: 487-497

ZLATKIS, A, ZAK, B, BOYLE, AJ 1953: A new method for the direct determination of cholesterol. J Lab Clin Med 41: 486-490 